\title{
Beak Line and Eye Alignment as Phenotypic Sexing for Domestic Canaries (Serinus canaria)
}

\author{
AFIF MUHAMMAD AKROM ${ }^{1}$, SOEDARMANTO INDARJULIANTO $^{2 *}$, YANUARTONO $^{2}$, \\ TRINI SUSMIATI ${ }^{3}$, ALFARISA NURURROZI $^{2}$, SLAMET RAHARJO $^{2}$, RIEF GHULAM \\ SATRIA PERMANA ${ }^{1}$, PUVEANTHAN NAGAPPAN GOVENDAN ${ }^{1}$ \\ ${ }^{1}$ Faculty of Veterinary Medicine, Universitas Gadjah Mada \\ Jl. Fauna No. 2, Karangmalang, Yogyakarta, Indonesia. 55281 \\ ${ }^{2}$ Department of Internal Medicine, Faculty of Veterinary Medicine, Universitas Gadjah Mada \\ Jl. Fauna No. 2, Karangmalang, Yogyakarta, Indonesia. 55281 \\ *Email: indarjulianto@ugm.ac.id \\ ${ }^{3}$ Department of Biochemistry, Faculty of Veterinary Medicine, Universitas Gadjah Mada \\ Jl. Fauna No. 2, Karangmalang, Yogyakarta, Indonesia. 55281
}

Received 16 November 2019; Received in revised form 23 April 2020;

Accepted 17 May 2020; Available online 30 June 2020

\begin{abstract}
Phenotypic sexing of birds is a common practice among the songbird-keeping community, yet it is based on non-reputable information. This study aims to determine the sex of canaries (Serinus canaria) based on the alignment of the eye with the beak line. A total of 26 samples, consisting of six samples of one-month-old canaries (three males and three females based on PCR examination), 20 samples of sixmonth-old canaries (ten proven breeding pairs) were used in this study. The birds' heads were photographed from the sides, and then the positions of the eyes were compared with the shadow alignment of the beak. The results provided that five young birds and ten adult birds have a beak line alignment under the eye, while ten adult birds and one young bird have a beak line alignment across the eye. The accuracy of sexing using this method was $100 \%$ for both female and male adult canaries. However, this result could not be applied to sample that are not yet sexually mature, as two young male birds were found to have beak alignment below the eye. It can be concluded that sexing adult canaries can be performed by observing the eye and beak line's alignment.
\end{abstract}

Keywords: beak line; eye; phenotype, sexing, songbird

\section{INTRODUCTION}

Canaries (Serinus canaria) are among the most globally common songbird kept among the bird keeping community (Mudawamah et al., 2012; Auzaini et al., 2013). In Indonesia, canaries are commonly kept among the bird keeping community because of the fascinating chirping sounds and the unique combination of their feather colors (Padmadi, 2010; Auzaini et al., 2013; Julita et al., 2015). Male canaries are favored due to the astonishing variety of sounds. Birds singing competition is commonly held among the bird-keeping community, and usually, the winners will be highly-priced. Good singing males are also used for producing good quality singing canaries. Therefore, sexing the canaries is beneficial for both the competition and as studs.

Bird sexing can be difficult, especially among monomorphic species (Doosti et al., 2009; Baehaqi et al., 2018). The morphology of males and females are very similar among the species (Cardoso et al., 2012; Abdollahi et al., 2018). Sexual characteristics in birds are recognizable after being sexually prepared for mating like birdsong is involved in female reproductive activity (Leboucher et al., 2012; Snyder \& Creanza, 2019). The canaries are birds that could be difficult to distinguish the sex at an early age and could only be distinguished when sexually mature.

Phenotypic and genotypic observations could be used as a method of sexing for this species. Bird keeping communities have unpublished methods of phenotypic observation method. Some modern methods that have developed in current years are laparoscopy and laparotomy to observe the gonads directly (Vucicevic et al., 2013; Divers, 2015), polymerase chain reaction (PCR) for gene study (Morinha et al., 2012), steroid sexing to observe the sexual hormone levels 
from eggshell and fecal samples (AdkinsRegan, 2007; Cerit \& Avanus, 2007; Abdollahi et al., 2018; Qasimi et al., 2018; Purwaningrum et al., 2019); genom evaluation and in silico approach (Ishijima et al., 2014; CaetanoAnolles et al., 2015; Rallabandi et al., 2019). DNA isolation could be collected from feather, blood, feces, buccal and cloacal swabs (Çakmak et al., 2017; Abdollahi et al., 2018; Asawakarn et al., 2018; Purwaningrum et al., 2019). Unfortunately, most modern methods are costly and rarely applied among the Indonesia bird keeping community. Therefore, alternative methods, which are a more consumer-friendly approach, could be applied among the community. Several methods of bird sexing have been developed among the bird keeping community. Morphological sexing of Cacatua galerita and Lonchura sp. based on beak shape is an example, but the results indicate no significant differences between male and female birds (Roslinawati et al., 2019; Zein et al., 2017). However, the bird community was developing a sexing method based on the beak's alignment with the eye on Geopelia striata and canaries. The assumption is the alignment of the beak under the eye is supposed to be a female. Meanwhile, the alignment of the beak past the eye is male. There is no scientific evidence yet for the application of this method. This study aims to determine the sex of the canaries based on the eye position with the beak line alignment. The study results are expected to be useful as a reference for the public, veterinarians, and zoologists to determine the sex of canaries.

\section{MATERIALS AND METHODS}

A number of six specimens of one-monthold canaries (confirmed as three males and three females) and 20 specimens of six-monthold canaries (confirmed as ten males and ten females) were used in this study. The sex of the one-month-old canary specimens was confirmed based on polymerase chain reaction (PCR) examination performed at the Department of Internal Medicine, Faculty of Veterinary Medicine, Universitas Gadjah Mada. Ten proven breeding pairs were randomly collected from a local canary breeder for head photography. All specimens' heads were photographed from the side. A straightline assumption was made between the upper and lower beaks, from the front to the back of the head. The beak alignment position was then compared with the eye position, with results of the beak line being under the eye or passes through the eye (Figure 1). The observation was then compared with every bird with the sex data and was analyzed descriptively.
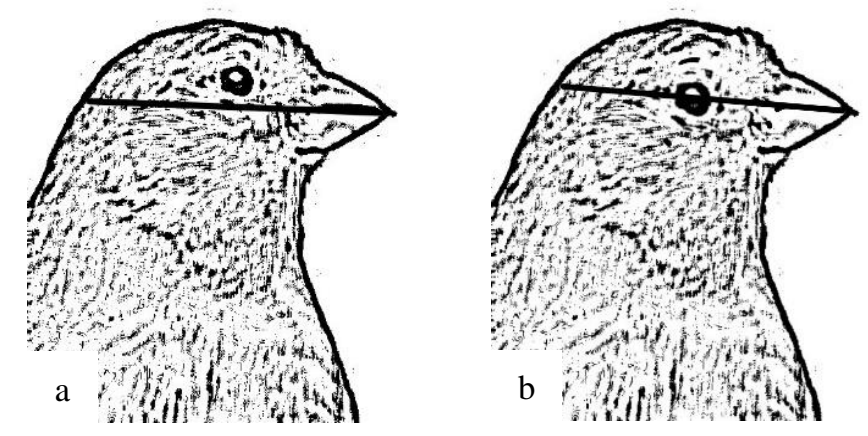

Figure 1. Position observation of the beak alignment with canaries' eye: a. the beak alignment is under the eye; b. the beak alignment goes through the eye

\section{RESULT AND DISCUSSION}

The results of the study on one-month-old canaries showed that five birds had the beak line below the eye, and one canary had a beak line across the eye (Figure 2). Among the six- month-old canaries, the results showed that ten birds had the beak line below the eyes and the other ten birds had beak line across the eye (Figure 2). 


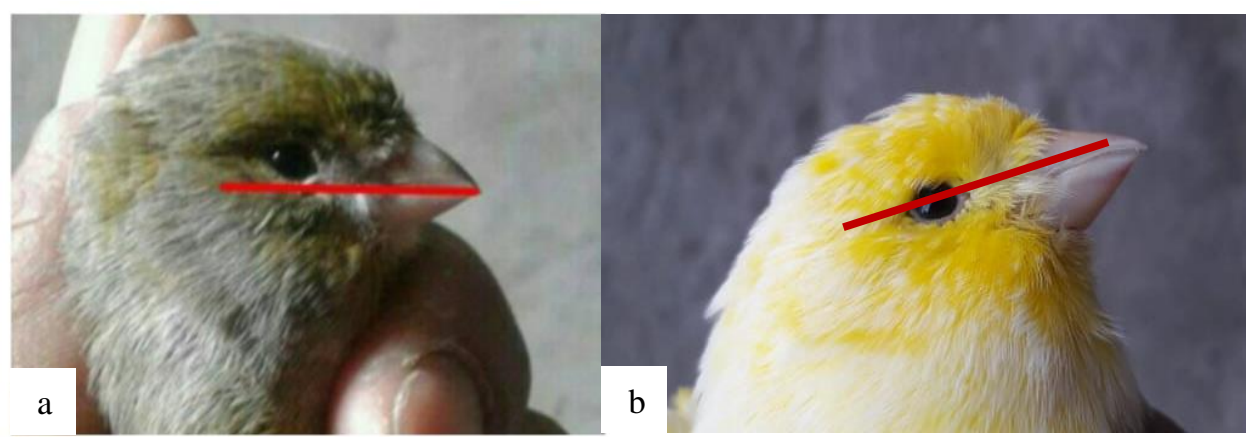

Figure 2. Relation of sexing method of canaries according to the alignment of the eye and beak: a. the line on the beak below the eye indicates a female; $b$. the line across the eye indicates a male

The information developed among the canary-keeping community by visual observation is that the alignment between the beak line and the eye can be performed at the age of seven-days-old. The interpretation of the study results on the one-month-old canaries is not following the previous sexing method consisting of three females and three males. The results showed errors in the method observed for one-month-old canaries consisting of three females and two males. This is likely due to the underdevelopment of the skull of a one-monthold bird. According to Agustina et al. (2013), birds' growth consists of fast and slow stages, where rapid growth occurs during hatchling until sexual maturity and then slows down.

Rapid growth and unequal anatomical growth among individuals cause a lack of consistency in the location of the beak line compared to the eye in male and female canaries aged one-month-old. Cranial growth development in short-tailed shearwater (Puffinus tenuirostris) occurs between the first and sixth months of life (Imamura et al., 2015).
This is also observed in a barn owl (Tyto furcata) (Franz-Odendaal \& Krings, 2019). This growing phase of the skull is believed to be the erroneous reason for the one-month-old hatchlings. The accuracy of sexing by morphometry of the beak and eye alignment in one-month-old canaries is $66 \%$. It is not a recommended sexing method of canaries at an early age. Sexing on young birds could still be performed using chromodomain helicase DNA (CHD) binding detection with PCR (Çakmak et al., 2017). Blood, feathers, tissue, buccal, and cloacal swab samples could be used in this method (Doosti et al., 2009; Çakmak et al., 2017; Purwaningrum et al., 2019). Eggshell corticosterone levels seem to be high in males than females in Japanese quails (Qasimi et al., 2018). This method could also be possible on the eggshells of canary hatchlings.

In contrast to the results of sexing the onemonth-old canaries, the six-month-old canaries showed that the alignment of the beak line and the eye gave positive results on all ten male and ten female canaries (Table 1).

Table 1. Observation results of the alignment of the beak line compared to the canaries' eyes

\begin{tabular}{|c|c|c|c|c|}
\hline \multirow{2}{*}{ Age } & \multirow{2}{*}{ Criteria } & \multirow{2}{*}{$\sum$ bird } & \multicolumn{2}{|c|}{ Sex (canary) } \\
\hline & & & Female & male \\
\hline \multirow[t]{3}{*}{1 month } & Beak line under the eye & 5 & $3 *$ & 2 \\
\hline & Beak line across the eye & 1 & 0 & $1 *$ \\
\hline & \multicolumn{4}{|c|}{ Accuracy $(3+1) / 6 \times 100 \%=66 \%$} \\
\hline \multirow[t]{3}{*}{6 month } & Beak line under the eye & 10 & $10^{*}$ & 0 \\
\hline & Beak line across the eye & 10 & 0 & $10 *$ \\
\hline & \multicolumn{4}{|c|}{ Accuracy $(5+5) / 10 \times 100 \%=100 \%$} \\
\hline
\end{tabular}

The six-month-old canaries are likely to have a completely grown skull, with the adult proportion of the head and eye in male and females. 


\section{CONCLUSION}

Sexing of a six-month-old canary can be determined based on the position of the beak alignment with its eye, but not on one-monthold canaries. This method can be applied to adult birds, but for six-months-old canaries or younger, must be further investigated.

\section{ACKNOWLEDGEMENTS}

This research has been approved with ethical clearance with the code of 0012/ECFKH/Int/2018 from the Veterinary Ethical Clearance Commit of the Faculty of Veterinary Medicine, Universitas Gadjah Mada, Yogyakarta. This research is funded by the Research Competitive Multidisciplinary Master's Program of the Veterinary Faculty of Universitas Gadjah Mada with the contract number 1584/J01.1.22/HK4/2018.

\section{REFERENCES}

Abdollahi H, Yeganeh HM, Shahrbabak HM. 2018. Sex determination in the canary based on the CHD gene located at the sex chromosome using feather. Iranian Journal of Animal Science. vol 49(2): 257265. http://doi:10.22059/ijas.2018.250993.653611.

Adkins-Regan E. 2007. Hormones and the development of sex differences in behaviour. Journal of Ornithology. vol 14891): 17-26. doi: http://doi: 10.1007/s10336-007-0188-3.

Agustina DP, Iriyanti N, Mugiyono S. 2013. Pertumbuhan dan konsumsi pakan pada berbagai jenis itik lokal betina yang pakannya di suplementasi probiotik. Jurnal Ilmiah Peternakan. vol 1(2): 691-698.

Asawakarn S, Teeranuwat I, Watcharaprapapong N, Siriwatchaiporn N, Somsai P, Kuldee M, Suriyaphol G, Dhitavat S. 2018. Comparison of dried blood spot, buccal swab, cloacal swab and feces as DNA sources to identify avian sexes by PCR. The Thai Journal of Veterinary Medicine. vol 48(3): 325-330.

Auzaini M, Mudawamah, Sunarto D, Fadli MZ. 2013. Variasi fenotipe morfometri burung kenari dewasa antara warna bulu terang kuning dan putih. Ternak Tropika Journal of Tropical Animal Production. vol 14(2): 31-37.

Baehaqi I, Saraswati TR, Yuniwarti EYW. 2018. Sex Determination in Male and Female Melopsittacus undulates using a Morphometric Method. Biosaintifika: Journal of Biology \& Biology Education. vol 10(3): 533-538. doi: https://doi.org/10.15294/biosaintifika.v10i3.14067.

Caetano-Anolles K, Seo M, Rodriguez-Zas S, Oh JD, Han JY, Lee K, Park TS, Shin S, Jiao ZJ, Ghosh M,
Jeong DK, Cho S, Kim H, Song KD, Lee HK. 2015. Comprehensive identification of sexual dimorphism-associated differentially expressed genes in two-way factorial designed RNA-Seq data on japanese quail (Coturnix coturnix japonica). PloS One. vol 10(9): 1-16. doi: https://doi.org/10.1371/journal.pone.0139324.

Çakmak E, Akın Pekşen Ç, Bilgin CC. 2017. Comparison of three different primer sets for sexing birds. Journal of Veterinary Diagnostic Investigation. vol 29(1): 59-63. doi: https://doi.org/10.1177\%2F1040638716675197.

Cardoso GC, Hu Y, Mota PG. 2012. Birdsong, sexual selection, and the flawed taxonomy of canaries, goldfinches and allies. Animal Behaviour. vol 84(1): 111-119. doi: https://doi.org/10.1016/j.anbehav.2012.04.015.

Cerit H, Avanus K. 2007. Sex determination by CHDW and CHDZ genes of avian sex chromosomes in Nymphicus hollandicus. Turkish Journal of Veterinary and Animal Sciences. vol 31(6): 371374.

Divers SJ. 2015. Endoscopic sex identification in chelonians and birds (Psittacines, Passerines, and Raptors). Veterinary Clinics: Exotic Animal Practice. vol 18(3): 541-554. doi: https://doi.org/10.1016/j.cvex.2015.05.006.

Doosti A, Fathpour H, Moshkelani S. 2009. Sex identification in the Canary using DNA typing methods. Bulgarian Journal of Veterinary Medicine. vol 12(3): 207-211.

Franz-Odendaal TA, Krings M. 2019. A heterochronic shift in skeletal development in the barn owl (Tyto furcata): A description of the ocular skeleton and tubular eye shape formation. Developmental Dynamics. vol 248(8): 671-678. doi: https://doi.org/10.1002/dvdy.65.

Imamura T, Kawarada S, Sugimori F. 2015. A possible determination of age in the short-tailed shearwater Puffinus tenuirostris based upon tissue and the layered structure of the mandible. Journal of the Yamashina Institute for Ornithology. vol 47(1): 116 https://doi.org/10.3312/jyio.47.1.

Ishijima J, Uno Y, Nishida C, Matsuda Y. 2014. Genomic structures of the $\mathrm{kW} 1$ loci on the $\mathrm{Z}$ and $\mathrm{W}$ chromosomes in ratite birds: structural changes at an early stage of $\mathrm{W}$ chromosome differentiation. Cytogenetic and Genome Research. vol 142(4): 255-267. doi: https://doi.org/10.1159/000362479.

Julita U, Fitri LL, Fuadah YT. 2015. Kemampuan belajar bernyanyi pada burung kenari jantan muda (Serinus canaria Linn.) yang didedahkan secara livetutoring dan tape-tutoring. Jurnal Istek. vol 9(1): 254-273.

Leboucher G, Vallet E, Nagle L, Béguin N, Bovet D, Hallé F, Ddraganoiu TI, Amy M, Kreutzer M. 2012. Studying female reproductive activities in relation to male song: the domestic canary as a model. Advances in the Study of Behavior. vol 44: 183-223. 
doi: https://doi.org/10.1016/B978-0-12-3942883.00005-8.

Morinha F, Cabral JA, Bastos E. 2012. Molecular sexing of birds: A comparative review of polymerase chain reaction (PCR)-based methods. Theriogenology. vol 78(4): 703-714. doi: https://doi.org/10.1016/j.theriogenology.2012.04.0 15.

Mudawamah, Susilowati S, Trijaya. 2012. Phenotype variation of $\mathrm{F} 1$ crossbreed derived from black throat with local canary birds (Serinus canaria). Ternak Tropika Journal of Tropical Animal Production. vol 13(1): 1-8.

Padmadi V. 2010. Register yang digunakan dalam tabloid burung edisi januari 2010. [Skripsi]. Yogyakarta: Department of of Indonesian Language and Literature, Universitas Sanata Dharma.

Purwaningrum M, Nugroho HA, Asvan M, Karyanti K, Alviyanto B, Kusuma R, Haryanto A. 2019. Molecular techniques for sex identification of captive birds. Veterinary World. vol 12(9): 15061513. doi: http://doi:10.14202/vetworld.2019.15061513.

Qasimi MI, Mohibbi H, Nagaoka K, Watanabe G. 2018. Accumulation of steroid hormones in the eggshells of Japanese quail (Coturnix coturnix japonica). General and Comparative Endocrinology. vol 259:
$161-164$.

doi: https://doi.org/10.1016/j.ygcen.2017.11.020.

Rallabandi HR, Yang H, Jo YJ, Lee HC, Byun SJ, Lee BR. 2019. Identification of female specific genes in the $\mathrm{W}$ chromosome that are expressed during gonadal differentiation in the Chicken. 한국가금학회지. vol 46(4): 287-296.

Roslinawati E, Prihatini W, Haryoko T. 2019. Variasi ciri morfometrik burung Bondol di Indonesia. Zoo Indonesia. vol 26(2): 116-129

Snyder KT, Creanza N. 2019. Polygyny is linked to accelerated birdsong evolution but not to larger song repertoires. Nature communications. vol 10(1): 1-15. doi: https://doi.org/10.1038/s41467019-08621-3.

Vucicevic M, Stevanov-Pavlovic M, Stevanovic J, Bosnjak J, Gajic B, Aleksic N, Stanimirovic Z. 2013. Sex determination in 58 bird species and evaluation of CHD gene as a universal molecular marker in bird sexing. Zoo Biology. vol 32(3): 269276. doi: https://doi.org/10.1002/zoo.21010.

Zein MSA, Haryoko T, Fitriana YS, Sulistyadi E, Prawiradilaga DM. 2017. Aplikasi kajian DNA molekuler dan fenotipik pada program pelepasliaran burung kakatua. Jurnal Biologi Indonesia. vol 13(1): 157-169. doi: http://dx.doi.org/10.14203/jbi.v13i1.3105. 